\title{
Problem Study about Dynamic Comparative Advantage and the Upgrading of China's Industrial Structure
}

\author{
Yu Jing \\ Huang gang Normal University Business School, Huanggang Hubei China \\ 763915419@qq.com
}

Keywords: Dynamic comparative advantage , Industry, Structure upgrading

\begin{abstract}
With the cheap labor, land, resources and other traditional elements of the gradual loss of dividends, the Chinese industry ushered in a critical period of transition. The dynamic comparative advantage theory developed on the basis of the traditional static comparative advantage theory will affect the industrial structure adjustment. At the same time, industrial upgrading is to achieve dynamic comparative advantages, the future of China can achieve from the traditional comparative advantage created labor-intensive manufacturing division of labor in the lock out, the key lies in whether we can achieve in the new round of industrial restructuring process, shaping the dynamic comparative advantage, and optimizing and upgrading the industrial structure.
\end{abstract}

\section{Introduction}

David Ricardo's theory of comparative advantage is the cornerstone of classical trade theory, which in a concise manner articulates the proposition of how and why trade is to be done between nations. The theory of comparative advantage has been always the focus of economic research, but also has become a national (regional) industrial policy guideline. But what exactly is the comparative advantage? What is the origin of comparative advantage? Academics have different views. The traditional static comparative advantage theory holds that the comparative advantage is the comparison of price competition and opportunity cost, and the source of comparative advantage is the difference of factor endowment. This argument is a good explanation of the division of labor between industries and north-south trade. However, with the development of economy, intra-industry trade, North-North trade, intra-industry division of labor and other new trade phenomena, we find that the comparative advantage is not immutable; the comparative advantage of industrial will appear between countries. And then enterprise competition is not simply the advantage of cost price, more to heterogeneous product advantages, technological superiority, management advantages, the advantages of network marketing, system advantages and infrastructure conditions. The factors which affect the comparative advantage are from single factor endowment to comprehensive factor endowment, from factor endowment to human capital accumulation and technology level etc.

The theory of dynamic comparative advantage expands the concept that the combination of factors into production capacity and the ability of value realization, but also a source of comparative advantage. In our view, comparative advantage refers to the comparative advantage factor and the sector with comparative advantage's change, caused by accumulation of factors and technological progress resulting in improved quality of elements and the emergence of new higher-level elements, thereby enabling the comparative advantage sector to upgrade or the comparative advantage division to enhance the status of the division of labor. It can be said that after the expansion of the concept and connotation of comparative advantage, the rise of factor prices is not the main factor effective the comparative advantage. The control of link and profit and the dominance of distribution in the global value chain division of labor are the most important factor in determining comparative advantage. , The control and monopoly of transnational corporations on the high-end links of the industrial chain, 
and the price war between Chinese enterprises are the root of the trade patterns and comparative advantage of China and developed countries.

The theory of dynamic comparative advantage is the extension and development of static comparative advantage theory analysis. The core idea is to relax some assumptions of static comparative advantage, such as the change of resource endowment with time and the importance of the factor in the new economic environment, the formation of new elements and so on. Compared with the traditional theory of comparative advantage, we can use dynamic economics to understand the dynamic comparative advantage: when a country in a sector of the opportunity cost's growth rate of production activity is lower than in other countries, the country in this sector Production activities have a dynamic comparative advantage. Unlike the static comparative advantage, the dynamic comparative advantage placed more emphasis on the potential and potential advantages of the developed country under certain conditions. The static comparative advantage strategy emphasizes the full use of the comparative advantage endowment of the current period, and thinks that the rapid economic growth can be achieved only by participating in the international division of labor according to the comparative advantages of the current period; the dynamic comparative advantage strategy emphasizes the dynamic of comparative advantage the use of existing comparative advantages, through efforts to promote the comparative advantage to a higher level of conversion and economic Longer-term, more efficient development. In general, the research on the theory of dynamic comparative advantage is divided into three main categories: the theory of dynamic comparative advantage is based on factor change, technological progress and other factors.

\section{The dynamic change of China's industries' comparative advantage and its problems}

The dynamic change of comparative advantage of china's industrial development. According to the static comparative advantage, the international division of labor is divided by the factor-intensive industries to start. For example, developed countries, capital, technology-intensive, to focus on capital-intensive, technology-intensive products, while developing countries is focused on labor-intensive labor-intensive industries. This is the global division of labor between the north and south of the direct embodiment of trade. China uses abundant labor force elements to engage in the production of labor-intensive industries and participate in the international division of labor with labor factors. However, with the increase of labor cost and the increase of land cost and environment cost, the advantage of labor cost in neighboring low-income countries is obvious, and our traditional comparative advantage is losing gradually. If we continue to participate in international divisions of labor according to the traditional static comparative advantage, China's industry will likely fall into the labor division of labor-intensive industries of low-end traps. This is mainly reflected in the lack of key links in R \& D, design, branding, marketing, supply chain management and deepening of labor division in the international industrial division of labor in the low-end value chain, the low value-added economic activities; a large number of Chinese enterprises focused on the processing and manufacturing sectors also caused excessive competition between enterprises and overcapacity, leading to deterioration in terms of trade, trade friction intensified. Therefore, China should avoid the fate of the low-end locked in the global division of value chain and profit distribution, must be in the process of economic development, and constantly upgrade their comparative advantage connotation, the pursuit of dynamic comparative advantage.

The defects of China 's dynamic comparative advantage transformation mechanism. First of all, self-creation mechanism also lacks the necessary support. Although the total economy in China has a large country on the characteristics, neither the product of technical knowledge content or value-added products is not relatively obvious improvement. Taking industry as an example, although the import and export of high-tech products in China surged for the first time in 2004, the proportion of foreign-funded enterprises has been overwhelming (65\%), and China's independent innovation capability has not been substantial. These shows that China's economic development 
capacity is not strong, most of the industry are in the low-end value chain, can only get low value, the ability to resist risks is weak. Second, the mechanism of government's role in urgent needed for transformation. In the cultivation of the traditional comparative advantage, the government is often keen to pursue rapid economic development through direct large-scale investment. This quick-profit approach also causes much non-market-oriented industrial isomorphism and overcapacity. This result making the price war has become a common method of competition in Chinese enterprises, many Chinese industries are lost in this vicious cycle of promotion opportunities, which to some extent, weakened China's competitive advantage. Moreover, the more serious is the development of new industries, many local governments in China there have been blind expansion of the tendency of the extensive development of high-tech industry trends become increasingly evident that this path dependence may be caused by China's industrial transformation and upgrading great damage.

\section{Suggestions on constructing dynamic comparative advantage in china}

Although the number of labor in China can be called a large country of human resources, can not be called the power of human capital, and the labor force of the "dual structure" has become a bottleneck restricting China's current economic development. In this case, how to achieve human resource advantage to human capital advantage is the transformation of China's economic development stage objective requirements. To improve the accumulation of human capital is not only to increase the investment in education, not simply to improve the level of education; the key is that some institutional obstacles hinder the full play of human capital. Due to the division of the labor market in China for a long time, the household registration system, the employment system and the social security system have seriously affected the reasonable flow and effective allocation of human capital. And it is difficult to make a breakthrough in the reform of the single system. Therefore, it is necessary to form a unified coordinating mechanism to realize the smooth flow of human capital. And take the direct and indirect measures to promote the accumulation of human capital, improve the human capital structure, improve the production efficiency of human capital. More importantly, stimulus signals to encourage investment in human capital are provided by enhancing the competitiveness and free-flow capabilities of the labor market. The key to the promotion of human capital accumulation in China is to improve the return rate of human capital investment. In this process, skills training as an important way the same can not be ignored. Practice shows that skills training can enhance the accumulation of human capital, and in the short term will be able to receive satisfactory results, which is to train a large number of our urgent need of industrial technology workers an important means.

Factor endowment still plays a most important role in promoting a country's export and moldings comparative advantage, but its function must be combined with institutional factors and with the characteristics of the industry. Financial development, education development, intellectual property protection and the level of the legal system and other factors and the degree of financial dependence, work complexity, intensity and specific investment links, the synergies of these industry characteristics is to promote the export of Chinese industries as a whole power. In the current growth in labor costs in China, the initial factor endowment advantage compared to other Southeast Asian countries and regions is no longer dominant in the background, China's export power has not only rely on labor resources and natural resources, should also be fully the use of intangible institutional resources, through institutional changes to get "system bonus", and in order to create a new industry comparative advantage.

Local governments should formulate and develop related strategic new industries on the basis of clarifying the comparative advantages of the region, and gradually form a regional point of strategic new industries with prominent and differentiated development and improve the success rate of strategic new industries. 


\section{Acknowledgment}

Hubei Provincial Department of Education Humanities Project funding, Hubei to undertake the eastern part of the industrial transfer path selection and policy orientation, the item number: (item number: 15Y155) ,Hubei province university humanities and social sciences key research base project "Dabie mountain tourism industry regional influence analysis" (item number:2014001403) fund.

\section{References}

[1]GanChunhui ,YuDianfan . Strategic Research on Constructing Dynamic Comparative Advantage in China [J] Academic Monthly(2013)

[2]HouGaolan , Comparative Advantages, Backward Advantages and Backward National Industrial Upgrading [J] Development Research (2006)

[3]ZhangQizai ,The Evolution of Comparative Advantage and the Choice of Industrial Upgrade Path in China [J] China Industrial Economy(2008) 